\title{
繊維素グリコール酸の研究
}

（京都帝國大學工業化學喜多砸究室）（炤和二年九月一门日受理）

\section{工學士：櫻 回一即}

エチルアルコールにナトリウムを作川せしめてナトリウムアルコラートを造り之にモノクロル 醋酸を作用せしむれ洼チルグリコール酸を生ず之と同榜にアルカリ㵶維素にモノクロル醋酸を 作用せしむれば繊維素グリコー几酸を得

$$
\mathrm{X} \cdot \mathrm{OH} \cdot \mathrm{NaOH}+\mathrm{Cl} \cdot \mathrm{CH}_{2} \mathrm{COOH} \longrightarrow \mathrm{X} \cdot \mathrm{O} \cdot \mathrm{CH}_{2} \mathrm{COOH}+\mathrm{NaCl}+\mathrm{H}_{2} \mathrm{O}
$$

アルカリ繊維溸

$$
\text { 繊維素グリコール酸 }
$$

此化合物はヤンゼン氏(Jansen)に依り造られ纎維素醋酸と呼ばれたり(D. R. P. 332203,1921) ホイザー氏(Heuser)は上の特訢を其落書中に引用し之を纎維素グリコール酸と名附けたり(Emil Heuser, Lehrb. Cellulose Chem., 1923, 2 Aufl., 81)リリェンフェルト氏(Lilienfeld) ๖ヤンゼン氏 と略同一要旨の特部を得たり（E. P. 231810，1924）即ち其研究は特許にとぶまり學術的研究の 發表せられたるもの殆ど全く無し

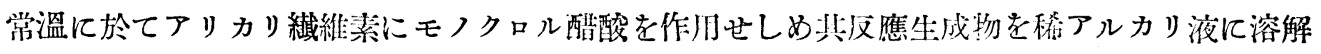
し後酸或は酒精を㧈へて繊維素グリコール酸を沈澱せしむ此物は水アルコール有機溶劑等に不溶 解性にして 5-10\%のアルカリには溶解し清澄粘椆なる溶液となり其より透明强靶なるフィルム。 絲等を造り得

著者は其化合物がェーテル酸なる故比較的安定なる事、瀻維素に遊離のCOOH基の結合せる化 合物なる事、容易に常溫にて可容性化合物の生ずる事、其組成性質がヴィスコースに類似せる事等

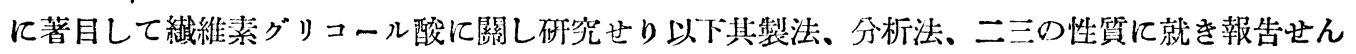

\section{繊維素グリコール酸の製造並に精製法}

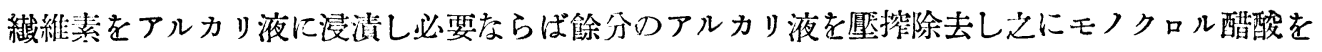
成る可く少量の水に溶解して作用せしむ反㣹は常溫或は氷で外部より椧却しつょ行ひ一書夜後終 るアルカリ液は湄厚なるもの例へば 40-50 容量\%のものを用ふる方よしモノクロル醋酸は全苛 性曹達量に對し其當量より少く、牛分或は幾分それ以下を朋ふるをよしとす。然らざれば苛性曹 楜はモノクロル醋酸の中和に費されェーテル化は行はれ難し此の點より云へばモノクロル醋酸の 曹澾監を用ふる方さし、然る時はアルカリ液は 20 容量\%の稀薄なるものにても反應は容易に進 み全部水に溶解するものを得

粘製法としては反應生.成物に酒精を加へ沈澱せしむればよし再沈澱を數回內至十數问反覆すれ 
ば過剩のアルカリ及監類は除去さる估ダイアリシスに依り製精するを得べし此方法にて得らる」 ものは緎維素グリコール酸の曹達鹽なり此のものは上述の如く殊にアルカリ液には容易に溶解す 纎維素グリコール酸を得るには上の曹達監を可なり稀薄なる水溶液にし之に鑛酸を加へて複分解 するを要す此繊維素グリコール酸は水に不溶解性なれども稩薄液にては極めて細く沈澱し肉眼に ては認め難し液を濃厚にし或は酒精を加ふれば沈澱朋瞭となろアルコール、水の適當の混合溶液 にて洗滌し或はダイアリシスにて精製し得緎維素グリコール酸は挂性アルカリ液中には其監類を

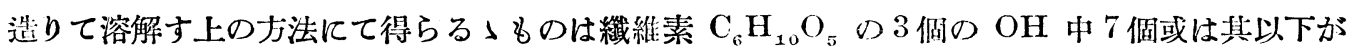
エーテル化されたるに過ぎすェチル或はメチル緎維素生成の時は比較的容易に高度のェーテル化 物を得れども此場合にはェーテル化を繰り反へすも瀻維素モノグリコール酸以上のものを得る事 困難なり纎維素モノグリコール酸に相當するものは容易に遥り得

分析法に應用せられ得べさ諸性質

電壓滴定 繊維素グリコール酸の酸アルカリ及指示藥に對する性質を知る雹に水素電極を用ひ

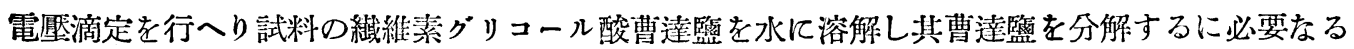
量より過剩の鹽酸を加入苛性曹達にて逆滴定を行ふ繊維素グリコール酸は水に不溶解性なるも沈 澱は極めて微細にて且膨化せる故に容易に苛性曹淦こて中和滴定し得滴定曲線は第一圖の如し
第 一 圆 (試料 1)
第：圖 (試料 2)
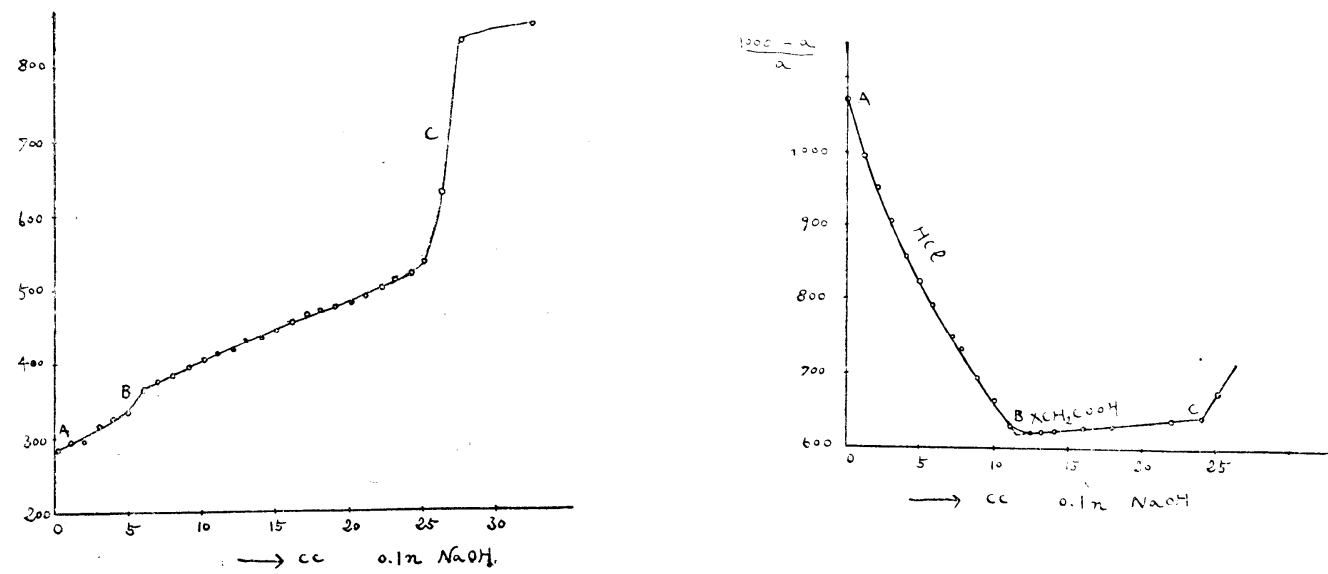

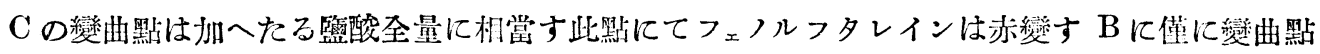
を認む次の電導度滴定より明膫なる如く此點は過剩の監酸の中和の終曲點にして BC の部は繊維 素グリコール酸の中和曲線なり

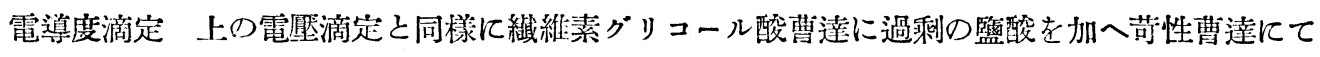
逆滴定せり一例は第二圖の如く $\mathrm{B}$ 及び $\mathrm{C}$ に明瞭庆万變曲點を認む、AB は餘分の監酸の中和曲

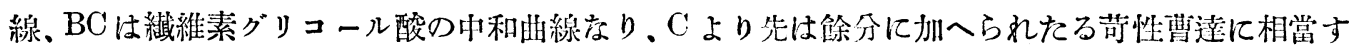


變曲點明膫なるが故に分析法として使用し得べし此電壓滴定及び電導度滴定は以下に誌す分析法 の基準となる

酒精にて沈澱せしめて分析するす法 㵶維素グリコール酸曹達を水に溶解してれに過剩の硫酸 を加へて曹達監を分解し酒精を加へて纎維素グリコール酸を沈澱せしめ滤過し濾液をフェノルタ レインを指示藥として逆適定を行ひ曹達鹽の分解に費されたる硫酸の量を知る分析法として好適 なり電導度滴定に化る結果とよく一致す

纎維素グリコール酸のアルカリ中への溶解 上述の結果よリアルカリ液に緎維素グリコール酸 を溶解せしめフェノルフタレインを指示藥として過剩の苛性曹達を滴定せば繊維素グリコール酸 の中和に費されたる苛性曹達量を知り從つて繊維素グリコール酸は此方法により分析せられ得べ きてと想像さる實驗は豫期通りの結果を與ふ

灰分の滴定 緎維素グリコール酸曹澾を灰化せば絬合ナトリウムは酸化ナトリウム或は炭酸ナ トリウムの如きアルカリとなる之を水に溶解し硫酸を加へて募沸しフェノルフタレインを指示藥 として荷性曹澾にて逆滴定を行ふ之より結合ナトリウムを知るを得へし此實驗結果は上の諧方法 と一致列に溶解し難き試料の分析に適當なるぺし

繊維素グリコール酸の他の二三の性質

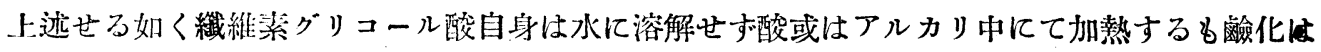

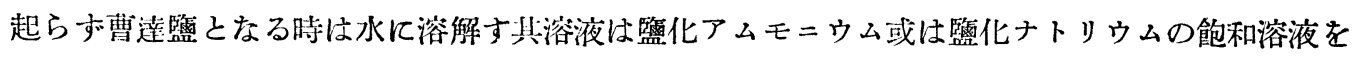
加へて監析するてと困難なりアルコール、アセトン等を加ふれば沈澱す一般に有機溶劑には不溶 解性なり繊維素グリコール酸曹達艋の水溶液に墭化バリウム、硫酸亞鉛、硝酸銀、硫酸銅の溶液 を加ふれば複分解にてそれぞれの監を沈澱す其中比較的棈製容易なる銅盬につき分析せり其結果 によれば銅結合量はト述の曹達鹽の曹澾結合量と可なりよく一致し曹達鹽は複分解により完全に

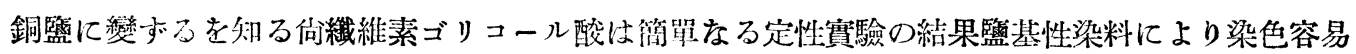
なるを認めたり义曹澾監はヴィスコースと共に均一なる溶液をつくる

實 驗 の 部

㵶維菜グリコール酸の製法

エーテル化の條件は大體に然て次の如し 空氣乾燥チッシュ紙 $10 \mathrm{~g}$ を一書夜アルカリ液に浸漬

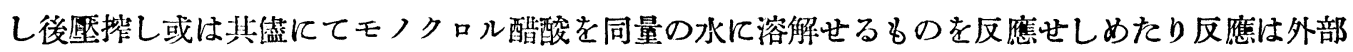
より水にて冷却しつ」行ひ一書夜後終れりアルカリの濃度使用量及モノクロル醋酸の使用量反應 生成物の分析等第一表の如し試料中＊印を附せるものはモノクロル醋酸を反應前重炭酸曹達にて 中和せるものなり精製法はフェノルフタレインに無色になる迄酒精による再沈澱を繰り返し或は ダイアリシスに依れり（織維素グリコール酸曹達の電離度は極めて小なる故に徒に長時間ダイア

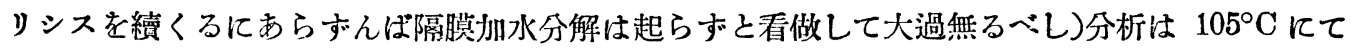


乾燥せる試料を用ひ大部分は酒精沈澱により行へりたよ゙水に不溶解性のものは灰分の滴定によれ b

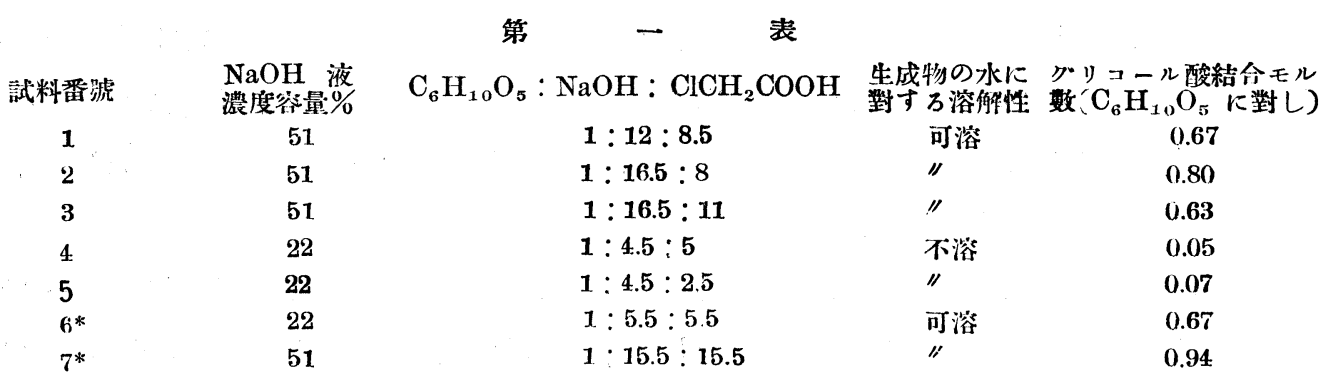

此の賽驗に於ては高度のエーテル化物を得る最適條行を求めたるに非ずェーテル化の二三の條 件を變更したるのみ、試料番號 7 より明なる如く高濃度のアルカリ液を用ひモノクロル醋酸の曹 達鹽を反應せしむれば一包の處理にて殆どモノェーテルに相當せるものを得

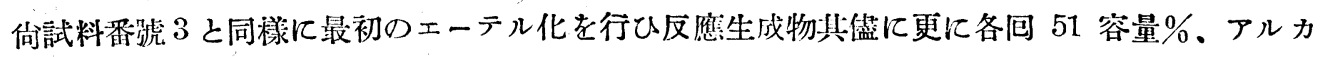

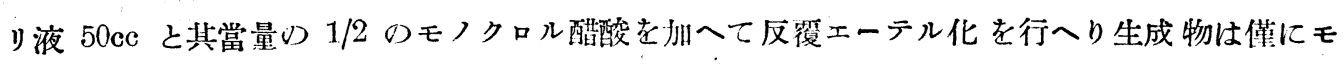
ノェーテルより幾分酸結合率多きて過ぎず反應進行の狀態は次の如し

$\begin{array}{lcccc}\text { ×ーテル化の包數 } & 1 & 2 & 3 & 5 \\ \text { グリコール酸結合モn } & 0.54 & 0.90 & 1.08 & 1.08 \\ \text { 數 }\left(\mathrm{C}_{6} \mathrm{H}_{10} \mathrm{O}_{5} \text { に對し) }\right. & & & & \end{array}$

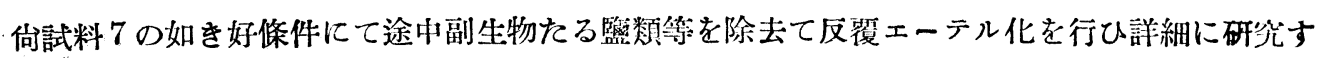
る必要あらん

繊維素のグリコール酸の州質埌に分析

電壓滴定 水素電極としてはヒルデブラント(Hildebrand)型のものを用ひ甘永電極の監化カリ

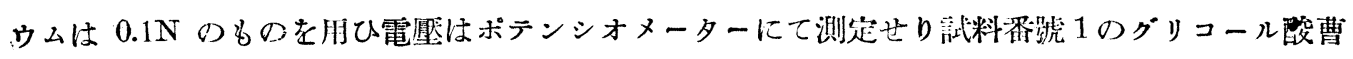
達 $0.5680 \mathrm{~g}$ を水 $100 \mathrm{ce}$ に溶解し後 $0.1 \mathrm{~N}-\mathrm{HCl} 25 \mathrm{cc}$ を加ふ $\mathrm{XCH}_{2} \mathrm{COONa}$ は $\mathrm{XCH}_{2} \mathrm{COOH} に$ 分解さる、此のものは元來水に不溶解なるも極めて細汇沈澱して殆ど肉腿にて認むる能は和此を

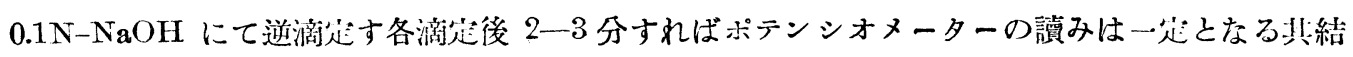
果は第一圖に示したる如し $\mathrm{BC}$ 線は $\mathrm{XCH}_{2} \mathrm{COOH}$ の中和曲線なるも $\mathrm{B}$ の變曲點著しからす

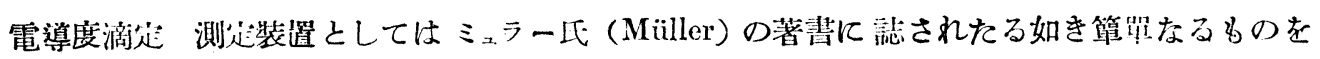
用ふ(E. Muller, Elektr. Prakt., dritte Aufl., 240) 試料瀻維素グリコール酸曹逰監約 $0.5 \mathrm{~g}$ を水

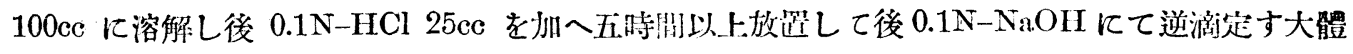

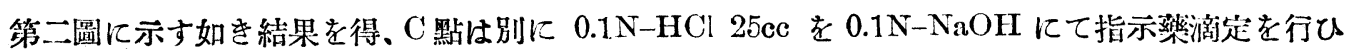
正確に求むコロイド溶液なる故に面の溶液の場合より變曲點を正確に求むるは幾分困難なれども 可なりよく一致せる好結果を得、芸料 1 及 2 とつき實驗せる結果を示す 


\begin{tabular}{|c|c|c|c|}
\hline & & $=$ & \\
\hline 試料 & 物質 $\mathrm{g}$ & 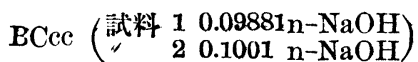 & $\mathrm{Na}$ 絬合量\% \\
\hline 1 & 0.5180 & 15.8 & 6.93 \\
\hline 1 & 0.6063 & 18.8 & 7.05 \\
\hline 1 & 平均 & & 6.99 \\
\hline 2 & 0.4051 & 14.55 & 8.25 \\
\hline 2 & 0.3956 & 14.25 & 8.29 \\
\hline 2 & 本均 & & 8.27 \\
\hline
\end{tabular}

酒精にて沈澱せしめて分析する方法 繊維素グリコール酸曹達約 $0.15 \mathrm{~g}$ を約 $20 \mathrm{cc}$ の水に溶解

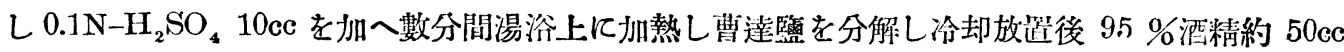

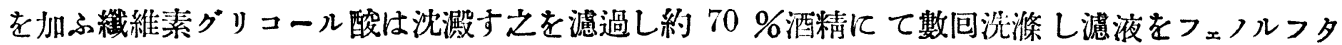
レインを指示藥とし $0.05 \mathrm{~N}-\mathrm{NaOH}$ にて逆滴疋走す同一條件の下に分析せる數例は第三表の如し此 種の緎維素誘導體の分析としては滿足し得べき程度に一致せる價なり試料 1 及び 2 に就て見る に電導度滴定法に依る絬果とよく一致す

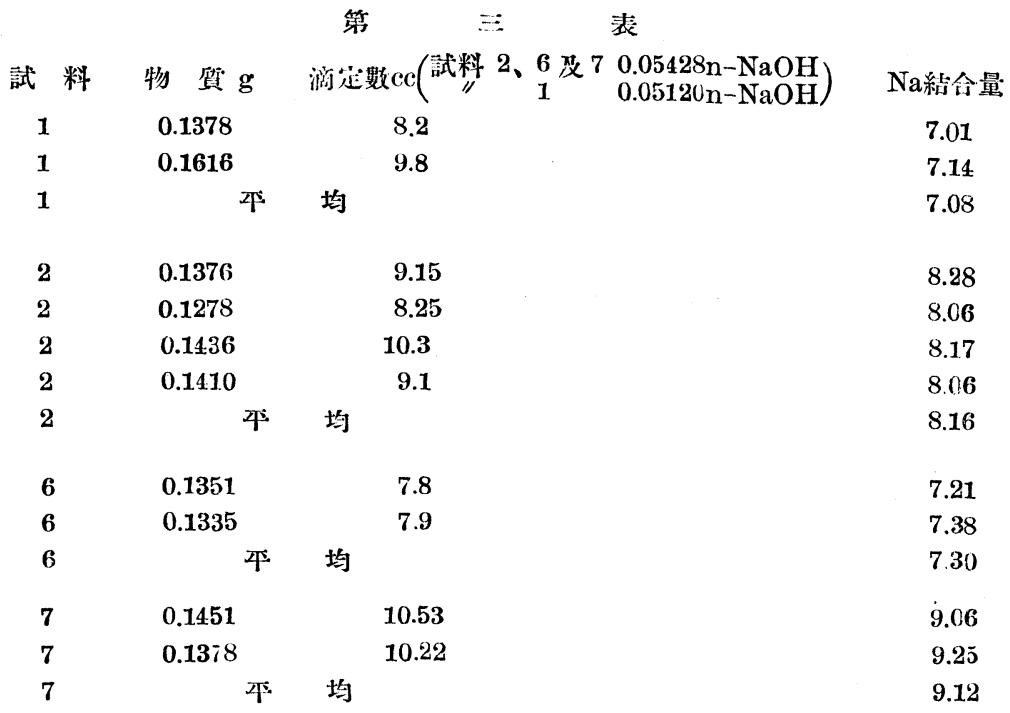

灰分の滴定 緎維素グリコール酸曹達約 $0.5 \mathrm{~g}$ を白金クルーシブル中にて徐々に完全に灰化し 灰分に水を加へビーカーへ移し $0.1 \mathrm{~N}-\mathrm{H}_{2} \mathrm{SO}_{4} 25 \mathrm{cc}$ を加へ 湯浴上に少時加熱し後フェノルフタレ インを指示藥とし $0.1 \mathrm{~N}-\mathrm{NaOH} に て$ 逆滴定す白試驗との差より木綃纎維素本來の灰分のアルカ リ性に相當する cc を除けるものは緎維素グリコール酸曹達の曹達に相當す此場合は基本緎維素 本來の灰分のアルカリ性は試料 $0.5 \mathrm{~g}$ に龁し $0.1 \mathrm{~N}-\mathrm{NaOH} 0.4 \mathrm{cc}$ とせり (J.Tex. Inst. 1926, $46 \mathrm{~T}$ 参照) 數例を示せば第四表の如し

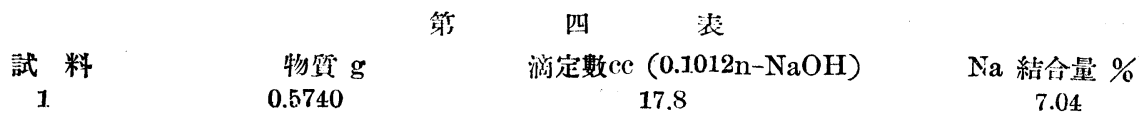


2

2

2
0.5173

0.2379
18.05

9.81
8.14

8.07

8.11

此方法に上る分析も上に示せる力法と一致せる絬果を與ふ

織維素グリコール酸のアルカリ中への溶解＼cjkstart試料瀻維素グリコール酸約 $0.15 \mathrm{~g}$ を $0.1 \mathrm{~N}-\mathrm{Na}$

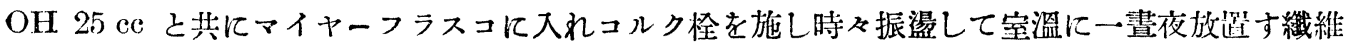
素グリコール酸は曹逞監となり溶解しアルカリを消費す過剩のアルカリを $0.1 \mathrm{~N}-\mathrm{H}_{2} \mathrm{SO}_{4}$ にて逆 滴定す加熱すれば次第汇餘分のアルカリを消費して一定の䋹果索得品、二三の賽驗を示せば第五. 表の如し

\begin{tabular}{|c|c|c|c|}
\hline & & 表 & \\
\hline 試 料 & 物 質 & 消費アルカリ cc $(0.1014 \mathrm{n}-\mathrm{NaH})$ & $\mathrm{Na}$ 監としてNa結合量\% \\
\hline 1 & 0.1666 & 4.95 & 6.50 \\
\hline 2 & 0.1778 & 6.2 & 7.58 \\
\hline 2 & 0.1398 & 4. $\$ 5$ & 7.53 \\
\hline 2 & & 均 & 7.56 \\
\hline
\end{tabular}

此結果曹澾監としての曹達結合量は直接分析に低る結果よりも約 $0.5 \%$ 程少なり此理由は曹達 監を鑛酸にて分解して繊維素グリコール酸にする際グリコール酸基の結合量多き部は沈澱し難く 細粉となり機械的損失上なり賽際に 分析せるも为のは幾分結合少なるるのなりし 第ならんと思は る

\section{繊維素グリコール酸の金屬鹽類}

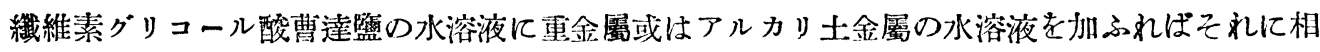
當する金屬㘕を沈澱す硝酸銀を加へて生ずる銀監の如きは最初は容易に遠心分離機により分離さ

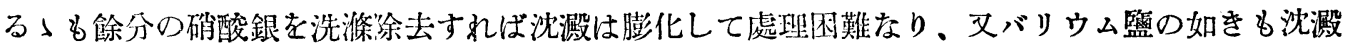

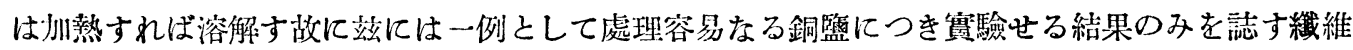

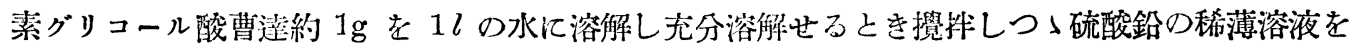

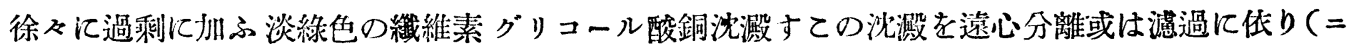
ユッツェを用ひ犽二重にて滤過す）充分洗滌し乾燥す乾燥すれば漫綠色となる $105^{\circ} \mathrm{C}$ の乾燥箱にて 恒量として分析す、分析は試料を灰化し銅を沃度メトリーに上り定量す分析結果第六表の如し

\begin{tabular}{|c|c|}
\hline 物 質 $\mathrm{g}$ & 湖定 $\operatorname{cc}\left(0.1000 \mathrm{n}-\mathrm{Na}_{2} \mathrm{~S}_{2} \mathrm{O}_{3}\right)$ \\
\hline 0.4553 & 7.45 \\
\hline 0.5002 & 8.30 \\
\hline 1.0055 & 16.45 \\
\hline
\end{tabular}

試料より製せ万銅暨

物 質 $\mathrm{g}$ 0.6824
第六表

潡定 cc $\left(0.1382 \mathrm{n}-\mathrm{Na}_{2} \mathrm{~S}_{2} \mathrm{O}_{3}\right)$ 8.85

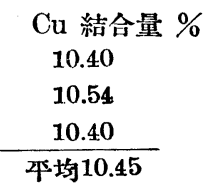

$\mathrm{Cu}$ 結合量 \% 11.40 
0.7231

第六表の平均 $\mathrm{Cu}$ 含付量より繊維素 $\mathrm{C}_{6} \mathrm{H}_{10} \mathrm{O}_{5}$ に對する其結合モル數を計算しナトリウム監の ナトリウム絬合モル數と此較せば

$\begin{array}{ccc}\text { 斌 料 } & \text { 銅絬合モル數 } & \text { ナトリゥム結合モル數 } \\ 1 & 0.36 & 0.67 \\ 2 & 0.43 & 0.80\end{array}$

銅は二價として結合モル數はナトリウム監のナトリウム結合モル數より幾分大なり其理由は第 一銅の存在汇任るにあらさるか大體に於て當量なるは疑ひの䟻地なし

本研究は帝國學士院の研究費補助により行ひたるものなり又研究上工學士岡田展三氏の助力に 負ふ所多し其厚意汇劃し感謝の意を表す

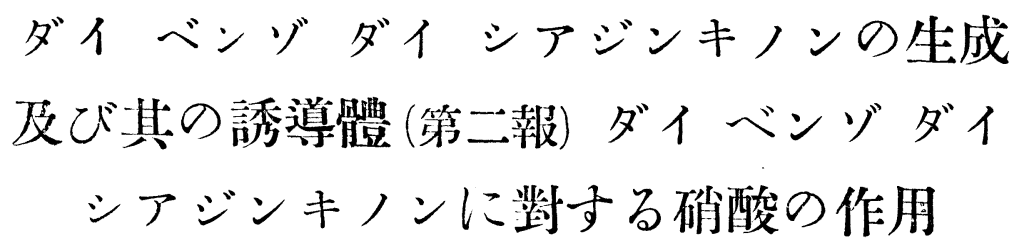

（來北帝國大學工學部化學工學孯賽駿室）（昭和二年九月一三日受理）

工學士柴田林之助

ダイベンゾ ダイ シアシシンキノン〔I]（柴田、本誌、第三○編、438頁)を硝酸によりて處理 すれ法オレーンジ II の如き外觀を付する粉末状物質を得、此のものは多くの有機溶劑に溶解せ すと踓も稀薄なるアルカリにた易く解け酸によりて再で沈澱す又そのソヂウム、ポタッシウム及 びつムモニウム化合物は何れも結晶として取り出す事を得例へば此の橙色の粉末狀物質を稀薄な る苛性曹達溶液の適量と數分間靜かに加熱すればソヂウム化合物を生成す赤褐色板狀結晶なりボ タツシウム化合物は針狀、アムモニウム化合物は板狀に結晶す此等は水に可溶性にしてアルコー ル其の他の有機溶劑に不溶性なり

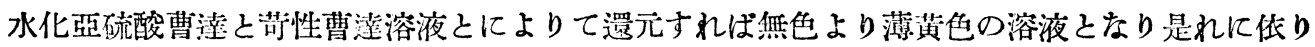
種々の纎維を青き色相に染める事は原の色素 ダイ ベンゾダイ シアシシンキノンに依ると全く同 样なり

分析の結果に低ればダイ ベンゾダイ シアシシンキンが硝酸に依りて受くる作用はナイトレ ーションには非ずして酸化なり即ちサイオエーテルからスルフォキサイドを生ずると同樣に二つ のシアジン環の中の硫黄原子が酸素原子と結合して相當するスルフォキサイド[II]を生ずるな り而して此の結果活性となれる二つのイミノ基の水素原子は金屬原子に依りて置換せられ得る性 